\title{
Inhibitory Effects of Three Dimensional Adipose Tissue-Derived Mesenchymal Stem Cell Conditioned Medium on Immune Response and Efficacy Evaluation of its Cream
}

\author{
Kyung Hye Kim ${ }^{1,2^{*}}$, Sunray Lee ${ }^{3}$, Hyun-Sook Park ${ }^{3}$ \\ ${ }^{1}$ Department of Cosmetology, Graduate School of Engineering, Konkuk University, Seoul, Korea \\ ${ }^{2}$ New Business Team, DongKoo Bio \& Pharma, Seoul, Korea \\ ${ }^{3}$ Stem Cell Niche Division, CEFO Research Center, Seoul, Korea
}

\author{
"Corresponding author: Kyung Hye Kim, \\ New Business Team, DongKoo Bio \& \\ Pharma, B-14F, 114, Beobwon-ro, Songpa- \\ gu, Seoul, Korea \\ Tel.: +82 7048645170 \\ Fax: +82 226811880 \\ Email: acting03@naver.com
}

Sunray Lee and Hyun-Sook Park contributed equally to this work.

Received October 19, 2018

Revised January 17, 2019

Accepted January 29, 2019

Published March 30, 2019

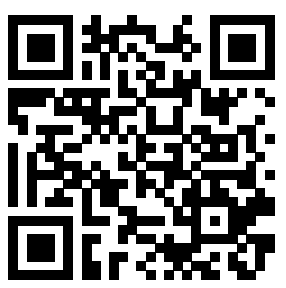

\begin{abstract}
Purpose: This thesis aims to confirm the skin-smoothing effects of 3D adiposetissue derived mesenchymal stem cell conditioned medium (3D-ADMSC-CM) and study how 3D-ADMSC-CM facilitates skin stimulation recovery. Methods: Since confirming that 3D-ADMSC-CM inhibits cell growth and immune reactions, we have continued to evaluate the effects of cream containing 3D-ADMSC-CM on human skin. Results: 3D-ADMSC-CM showed superior self-replication and cell growth rate (at 1, 3 and 5days), and the presence of interleukin 1 alpha (IL-1 $\alpha$ ) was reduced by 1.4 times, compared to LPS treated. We then applied 3D-ADMSC-CM to human skin. The skin irritation improvement and sedative effects by external stimuli (chemical stimulation) showed a decrease of $25.88 \%$ in the applied area and $22.20 \%$ in the non-dermal area after 3 weeks of use compared with before the test substance use (after SLS stimulation). Skin improvement due to the external stimulation (chemical) and soothing has been reduced after 3 weeks after use up to $25.88 \%$ of applied part and $22.20 \%$ of non-applied part compared to test material before use. The skin irritation sedative effect by physical stimulation (friction) immediately after one use showed $12.53 \%$ reduction of applied area and $8.71 \%$ reduction of non-applied part. Skin roughness was reduced after 3 weeks after use up to $15.91 \%$ of applied part and $3.16 \%$ of non-applied part compared to test material before use. The final results suggested improved keratin excitation and exfoliation has been reduced after 3 weeks after use up to $78.28 \%$ of applied part and $12.26 \%$ of non-applied part compared to test material before use. Conclusion: 3D-ADMSC-CM is effective and provides adequate skin stimulation. Cream contained 3D-ADMSC-CM soothed skin irritation improved the overall tone and texture of skin, and recovery of exfoliation by skin stimulation (chemical \& physical stimulation).
\end{abstract}

Keywords: Stem cell conditioned medium, Cosmetics, Skin irritation, Soothing, Efficacy evaluation

\section{Introduction}

피부는 표피, 진피, 피하지방으로 나뉘어 구성되어 있다. 그 중 표피는 피부의 가장 표면에 위치하여 외부 자극으로부터 피부 장 벽을 보호한다. 피부는 외부 환경에 지속적으로 노출되어 있어 자 외선, 열, 미세먼지, 물리적 자극, 화학적 자극 등에 지속적으로 공격을 받고 있다. 인체를 보호하기 위한 첫 번째 방어로써 작용
하기 때문에 면역반응들과 관련된 염증반응이 매우 빈번하게 일 어나게 된다(Baek et al., 2012). 염증반응이란 외상이나 세균 감 염 등의 외부 자극으로 인하여 인체 내에 유입된 항원에 대해 우 리 몸이 방어하는 작용으로써 정상적인 생체 반응이다(Lee et al., 2014 ; Lee \& Park, 2011). 이러한 염증반응이 장기적으로 진행 되면 아토피와 같은 피부질환을 악화시키는 원인이 되기도 한다. 
최근 생명공학의 발달은 화장품의 신원료 개발로 이어져 활발 히 연구되고 있다. 화장품, 제약 등 각 분야의 전통적인 산업에 의료 기술, 바이오 기술 등을 융합하여 건강, 환경 등을 고려한 새로운 화장품을 개발하는 형태로 뉴패러다임을 시도 하고 있다. 최근 들어 제약사들이 화장품 산업에 뛰어 들며 제약사들이 소유 한 바이오 기술을 근거로 고기능성 화장품을 연구 개발하여 출시 하기 시작하였다. 이처럼 화장품과 의약품의 경계가 무너지고 있 는 가운데, 기능성 화장품 산업의 발달과 더불어 코스메슈티컬 (cosmeceutical)은 화장품 산업의 새로운 시장(퍼플오션)으로 각 광받고 있다. 코스메슈티컬 화장품은 간단한 시술, 성형 이후 피 부를 관리해주는 보조적 치료를 목적으로 시작되었으나, 최근에 는 성별, 연령을 불문하고 데일리 케어 화장품으로 인식되어 소 비자들에게 주목을 받고 있다. 글로벌 안티에이징 시장을 주도하 고 있는 바이오 화장품은 줄기세포 화장품, 펩타이드 화장품, 유 전자 활성화 화장품 등이 있다.

줄기세포는 크게 성체줄기세포(adult stem cells)와 전분화 능 줄기세포(pluripotent stem cells)로 나뉘는데 전분화능 줄 기세포는 배아줄기세포(embryonic stem cells)와 역분화줄기 세포(induced stem cells)를 포함한다. 그 중에서도 성체줄기 세포는 배아줄기세포 대비 윤리적인 문제에서 비교적 자유로우 며 안전성과 재생능이 우수하고 다양한 성체 조직에 많이 존재 한다(Weissman, 2000; Weissman et al., 2001). 성체줄기세 포(adult stem cells) 중 하나인 지방유래줄기세포(adiposederived mesenchymal stem cells, ADMSCs)는 인체조직에 서 획득하기가 쉽고 배양방법도 까다롭지 않아 치료제 개발 뿐 만 아니라 다양한 측면에서 연구개발이 이루어지고 있다(Wilson et al., 2011). 지방유래간엽줄기세포를 배양하는 과정 중에 필 수적으로 이용되는 배양액은 세포 배양이 완료된 이후에는 폐 기되었으나 다양한 성장인자를 함유하고 있는 것이 확인되어 지방유래 줄기세포 배양액(adipose-derived mesenchymal stem cells conditioned medium, ADMSCs-CM)이라고 명명 하고 화장품 원료물질 등으로 적용하고자 하는 노력이 있어 왔 다(Kim et al., 2007; Kim et al., 2009). 지방조직은 많은 양 의 조직 채취가 용이하여 줄기세포를 수확하는데 좋은 조건을 가지고 있다(Strem et al., 2005). 줄기세포 배양액에는 EGF, $\mathrm{VEGF}$, collagen 등과 같은 다양한 성장 인자가 함유 되어 단 백질은 $\mathrm{mRNA}$ 발현을 촉진시키고 섬유아세포 활성을 촉진시켜 collagen 생합성을 증가시키기 때문에 주름개선에 효과가 있고 (Kim et al., 2009), nude rat를 이용한 상처 모델에서 상처치 유에도 효과가 있으며(Nakagawa et al., 2005), 피부의 산화적 스트레스에 작용하며 항산화 효과도 보인다는 보고가 있다( $\mathrm{Kim}$ \& Kim, 2011).

줄기세포 배양액 화장품은 줄기세포 배양과정에서 분비되는 다양한 성장인자를 포함하고 있는 줄기세포 조건화 배지를 포함
하고 있다(Schinköthe et al., 2008). 조건화 배지내의 EGF, $\mathrm{VEGF}$ 와 같은 성장인자와 세포 외 기질인 Collagen은 피부 재생 및 탄력 등과 같은 피부 노화방지 역할을 하고, $\mathrm{TGF}-\beta$ (전환성 장인자)는 미백 효과를 나타내는 것으로 알려져 있다. 조건화 배 지내의 인자들을 보호하고 피부 침투를 용이하게 하기 위해 대부 분 리포좀화 과정을 거쳐 화장품에 적용하고 있다(Jang et al., 2005; Jukanti et al., 2011). 화장품의 침투력은 조성물이나, 화장품을 흡수시키는 관리 방법에 따라 달라질 수 있다(Choi et al., 2012).

기존의 세포 배양 방법은 2 차원 배양접시(plate)에서 세포를 평판 배양하는 방법을 사용하였으며, 이러한 방식은 기능적, 형 태적, 유전자 발현적 측면에서 생체 내부와 같은 실제 환경과 많 은 차이를 보인다(Kenny et al., 2007). 3차원 배양은 생체 내 부 환경과 유사한 환경에서 세포를 배양시키기 위한 목적으로 연 구되었다(Breslin \& O' Driscoll, 2013). 다공성 고분자나 gel 등을 이용한 지지체 의존적 방법이 많이 사용되고 있으며, 3 차원 배양에서는 지지체의 선택이 중요하다(Sachlos \& Czernuszka, 2003). 최근 3 차원 구조의 지지체를 이용한 세포배양 방법이 지 속적으로 연구 개발되고 있으며, $3 \mathrm{D}$ 줄기세포 조건화 배지는 바 이오 화장품의 신원료로 각광받고 있다. 새로운 트렌드로 각광 받고 있는 '3차원(3D) 지방유래 간엽줄기세포 조건화 배지 화장 품'은 주름 개선으로 대표 되는 항노화 효과, 염증 억제 효과, 피 부 재생 및 상처치유 효과 등 피부 건강에 여러 효능이 있다. 최 근까지 2 차원(2D) 지방유래 간엽줄기세포 조건화 배지 화장품으 로 개발되어 출시되는 제품들은 일부 알려지고 있으나, 화장품의 안전성과 효능에 대한 연구는 매우 미미하여 이에 대한 단계적인 연구가 매우 절실하다.

이에 본 연구에서는 3 차원(3D) 지방조직유래 간엽줄기세포 조 건화 배지가 세포 성장률과 염증 억제 효과에 미치는 영향을 확 인하고, 3 차원(3D) 지방조직유래 간엽줄기세포 조건화 배지가 함유된 크림 타입 화장품이 외부 자극(화학적 자극), 물리적 자 극(마찰)에 의한 피부 자극 개선 및 진정효과에 대한 인체효능에 대해 평가하고자 한다. 이를 통해 향후 3 차원(3D) 지방조직유래 간엽줄기세포 조건화 배지가 함유된 크림 타입 화장품이 피부 진 정 및 피부 개선에 미치는 효능을 확인하며 화장품 신소재로서의 가능성을 제시하고자 한다.

\section{Methods}

\section{1. 세포주 및 세포 배양}

본 실험에 사용한 세포주는 20 세 이하의 남성 포피조직 유래 human dermal fibroblast (HDF, 인간피부유래 섬유아세포) 와 human epidermal keratinocyte (HEK, 인간피부유래 각질 
형성세포), human adipose tissue derived mesenchymal stem cell (hADMSC, 인간지방조직유래 간엽줄기세포)를 $\mathrm{CEFO} \mathrm{Co.}$ (Korea)에서 분양 받아 사용하였다.

1) 인간피부유래 섬유아세포는 CEFOgro ${ }^{\mathrm{TM}} \mathrm{HDF}$ (CEFO Co., Korea) 배지에 $1 \%$ penicillin/streptomysin (Gibco, UK) $(100 \mathrm{lU} / 50 \mu \mathrm{g} / \mathrm{mL}$ ) 을 첨가하여 $37^{\circ} \mathrm{C}, 5 \% \mathrm{CO}_{2}$ 상대습도 $95 \%$ 이상의 습윤 배양기에서 배양하였으며 계대 배양은 세포접종 3 일 후 실시하였다.

2) 인간피부유래 각질형성세포는 CEFOgro ${ }^{\mathrm{TM}}$ HK (CEFO Co., Korea) 배지에 $1 \%$ penicilin/streptomysin (100 IU / $50 \mu \mathrm{g} / \mathrm{mL}$ )을 첨가하여 $37^{\circ} \mathrm{C}, 5 \% \mathrm{CO}_{2}$ 상대습도 $95 \%$ 이상의 습윤 배양기에서 배 양하였으며 매일 동일한 시간에 배지를 교환하였다. 계대 배양은 세 포접종 4일 후에 실시하였다.

3) 3차원 방법(three dimensional method, 3D)의 지방 줄기세포 배 양

생분해성 합성 바이오겔(BASF, Germany)을 멸균된 3 차 증 류수에 $5 \%$ 부터 $30 \%$ 까지 $5 \%$ 간격의 농도로 녹여 다양한 농도의 겔을 제조한 후, $250 \mu \mathrm{L} / \mathrm{cm}^{2}$ 로 $0.4 \mu \mathrm{m}$ 내지 $1 \mu \mathrm{m}$ 인 폴리머막 (Corning, USA) 위에 도포하여 $90 \mathrm{~min}$ 동안 $37^{\circ} \mathrm{C}$ 에서 굳혀 3 차원 세포배양 환경을 만들었다. 그 후, 기존 배양 방법으로 배양 접시에서 배양한 인간 지방조직 유래 간엽줄기세포를 미리 겔화 를 진행한 생분해성 합성 바이오 겔 위에 접종하고 세포를 $37^{\circ} \mathrm{C}$, $\mathrm{CO}_{2}$ 배양기에서 배양한 후 세포가 안정화된 1 일 후 배양액을 교 환하였다.

4) 인간 지방조직유래 간엽줄기세포의 조건화 배지 확보

일반적인 세포배양 방식(2D)을 적용한 조건화 배지를 만들기 위해 $12,000 \mathrm{cells} / \mathrm{cm}^{2}$ 로 접종되어 1 일간 일반 배양접시에 배 양한 $\mathrm{ADMSC}$ 를 3 회 $\mathrm{PBS}$ 로 세척한 후 $\mathrm{CEFOgro}{ }^{\mathrm{TM}} \mathrm{XF} \mathrm{ADMSC}$ (CEFO Co., Korea)로 배지를 교환하여 $37^{\circ} \mathrm{C}, \mathrm{CO}_{2}$ 조건에서 1 일간 배양하였다. 그리고 배지만을 확보하여 $1,500 \mathrm{rpm}$ 에서 5 $\min$ 원심 분리하여 상등액만을 취하였다. 이후, $0.22 \mu \mathrm{m}$ 필터 로 필터하여 2차원(2D) 지방조직유래 간엽줄기세포 조건화 배지 (2D-human adipose tissue derived mesenchymal stem cell conditioned medium, 2D-ADMSC-CM)를 얻었다.

3 차원 $(3 \mathrm{D})$ 지방조직유래 간엽줄기세포 조건화 배지 (3D-human adipose tissue derived mesenchymal stem cell conditioned medium, 3D-ADMSC-CM) 확보를 위하여서는 $12,000 \mathrm{cells} / \mathrm{cm}^{2}$ 로 $\mathrm{ADMSC}$ 를 접종하여 $3 \mathrm{D}$ 방법으로 $\mathrm{ADMSC}$ 배양한 후 $\mathrm{PBS}$ 로 3 회 세척하고 $\mathrm{CEFOgro}{ }^{\mathrm{TM}} \mathrm{XF} \mathrm{ADMSC}$ (CEFO Co., Korea)로 배지를 교환하였다. 1 일간 $37^{\circ} \mathrm{C}, \mathrm{CO}_{2}$ 조건에서 배양한 후 배지만 확보하여 $0.22 \mu \mathrm{m}$ 필터로 필터하여 획득하였 다.

\section{2. 세포 성장률 측정}

인간피부유래 섬유아세포를 6 well 세포 배양 접시(Corning, USA)에 $5 \times 10^{3} \mathrm{cells} / \mathrm{cm}^{2}$ 의 세포를 접종한 후 $\mathrm{CEFOgro}{ }^{\mathrm{TM}}$ $\mathrm{HDF}$ 로 $8 \mathrm{~h}$ 배양하여 세포를 안정화 하였다. 세포가 완전히 부 착된 것을 확인한 후, $2 \mathrm{D}$ 지방조직유래 간엽줄기세포 조건화 배지와 3 차원 지방조직유래 간엽줄기세포 조건화 배지를 각각 $50 \%$ 의 농도로 $\mathrm{GEFOgro}^{\mathrm{TM}} \mathrm{HDF}$ 배지에 희석하여 준비하고 이 를 이용하여 배지를 교환하였다. 각각의 배양액을 처리하여 1 일, 3 일, 5 일 동안 $5 \% \mathrm{CO}_{2}, 37^{\circ} \mathrm{C}$ 인큐베이터에서 세포를 배양 하면서 세포성장을 확인하였다.

세포수 측정을 위해 세포를 포스페이트 버퍼 살린(phosphate buffer saline, PBS)으로 2회 세척한 후 trypsin/EDTA와 $37^{\circ} \mathrm{C}$ 에서 $5 \mathrm{~min}$ 반응시켜 세포를 탈착하고 포집하였다. 포집 된 세포는 $\mathrm{FBS}$ 가 함유된 $\mathrm{CEFOgro}{ }^{\mathrm{TM}} \mathrm{HDF}$ 배지로 trypsin/ $\mathrm{EDTA}$ 를 비활성화시키고 $\mathrm{PBS}$ 로 2 회 세척하여 준비하였다. 준 비된 세포 중 $20 \mu \mathrm{L}$ 를 취하여 ADAM-MC's Accuchip Kit (NanoEntek, Korea)로 염색한 후, 자동세포계수기인 ADAM$\mathrm{MC}$ (NanoEntek)를 이용하여 계수하였으며, 인간섬유아세포 배양액인 $\mathrm{CEFOgro}{ }^{\mathrm{TM}} \mathrm{HDF}$ 로 배양한 세포를 대조군으로 하여 2 차원 $(2 \mathrm{D})$ 지방조직유래 간엽줄기세포 조건화 배지와 3 차원 (3D) 지방조직유래 간엽줄기세포 조건화 배지 조건에서 배양한 줄기세포 조건화 배지의 세포수를 산출하여 도식화하였다. 세포 수 계수는 1 일, 3 일, 5 일 간격으로 일정한 시간에 실시하였다.

\section{Colony forming unit (CFU) 측정}

6 well 세포배양 접시에 500개/well의 세포를 접종한 후 7일 동안 $\mathrm{CEFOgro}{ }^{\mathrm{TM}} \mathrm{HDF}$ 배지와 각각 $50 \%$ 농도의 2 차원(2D) 지 방조직유래 간엽줄기세포 조건화 배지, 3 차원(3D) 지방조직유 래 간엽줄기세포 조건화 배지를 이용하여 $5 \% \mathrm{CO}_{2}, 37^{\circ} \mathrm{C}$ 인큐 베이터에서 세포를 배양하였다. 세포 콜로니가 시각적으로 인지 되는 크기로 자라는 7일째 세포 배양을 중단하고 PBS로 2회 세 척한 후 포름알데히드로 $5 \mathrm{~min}$ 상온에서 고정하였다. 고정 후 $\mathrm{PBS}$ 로 2회 세척하고 $0.2 \%$ crystal violet으로 $10 \mathrm{~min}$ 염색하 였다. 염색완료 후 $\mathrm{PBS}$ 로 3 회 세척한 후 잘 건조시켰다. 이후 콜로니의 개수를 계수하여 $\mathrm{CFU}$ 를 측정하였다.

\section{4. 면역반응 억제 효능 분석}

CEFOgro $^{\text {TM }}$ HK (CEFO Co., Korea) 배지에 $1 \%$ penicillin/ streptomysin $(100 \mathrm{IU} / 50 \mu \mathrm{g} / \mathrm{mL})$ 을 첨가하여 $37^{\circ} \mathrm{C}, 5 \% \mathrm{CO}_{2}$ 상대습도 $95 \%$ 이상의 습윤 배양기에서 배양된 인간피부유래 각질형성세포를 포집하여 96 well plate (Corning, USA)에 8000 cells $/ \mathrm{cm}^{2}$ 로 접종하고 $8 \mathrm{~h}$ 동안 $\mathrm{CEFOgro}{ }^{\mathrm{TM}} \mathrm{HK}$ 로 배양 하여 안정화 시킨 후 PBS로 2 회 세척하였다. 그리고 실험 조건 에 맞게 각각의 배지를 교환함과 동시에 항염 효능 여부를 확인 
하고자 면역반응을 유도하는 것으로 알려져 있는 리포폴리사카 라이드(lipopolysaccharide, LPS; Sigma-Aldrich, USA)를 대조군과 실험군에 각각 $2 \mu \mathrm{g} / \mathrm{mL}$ 씩 세포에 처리하였다. 그리고 interleukin 1 alpha (IL-1 $\alpha)$ 의 발현량의 증감을 확인하기 위 해 ELISA를 실시하였다. IL- $1 \alpha$ 의 발현 확인은 R\&D systems 의 IL- $1 \alpha$ ELISA kit를 이용하여 측정하였고 실험과정은 제조 사 제공 프로토콜을 참고하였다. 각 조건화 배지에 의한 IL-1 $\alpha$ 값의 보정을 위해 인간피부유래 각질형성세포를 접종하지 않은 대조군을 포함하여 ELISA분석을 실시한 후 각각의 배지조건에 맞게 보정하였다.

\section{5. 시험물질로 사용된 3차원(3D) 지방조직유래 간엽줄기세포 조 건화 배지가 함유된 크림 제형 화장품 제조}

Water phase를 메인 비커에 투입 및 교반하여 $80^{\circ} \mathrm{C}$ 까지 가온 하였다. 가온된 water phase에 liquid crystal emulsifier를 투 입하여 $80^{\circ} \mathrm{C}, 6,000 \mathrm{rpm}, 10 \mathrm{~min}$ 동안 homogenizer를 이용 하여 수화하였다. 별도 용해조에 oil phase를 투입하여 $80^{\circ} \mathrm{C}$ 까 지 가온 한 뒤, 메인 비커(water phase, oil phase 혼합)에 투 입 후 $75^{\circ} \mathrm{C}, 6,000 \mathrm{rpm}, 5 \mathrm{~min}$ 동안 homogenizer를 이용하여 유화하였다. 메인 비커의 water phase와 oil phase를 $45^{\circ} \mathrm{C}$ 냉 각화하였다. Liquid crystal capsule phase를 별도 용해조에서 교반하여 incapsulation화 시켰다. 메인 비커(water phase, oil phase 혼합)에 liquid crystal capsule phase를 투입 후 $45^{\circ} \mathrm{C}$, $6,000 \mathrm{rpm}, 3 \mathrm{~min}$ 동안 homogenizer를 이용하여 교반 후, 메 인 비커를 $33^{\circ} \mathrm{C}$ 냉각 후 탈포하였다. 본 인체적용시험에 사용된 시험물질은 3 차원(3D) 지방조직유래 간엽줄기세포 조건화 배지 가 $2 \%$ 함유된 크림타입의 시험용 화장품으로 준비되었다.

\section{6. 인체적용시험}

3 차원(3D) 지방조직유래 간엽줄기세포 조건화 배지가 함유 된 크림 타입 화장품의 인체적용시험을 통한 유효성을 확인하 기 위하여 임상연구 기관인 한국피부과학연구원(진셀팜)에서 진행하였다(승인번호: 1-70005239-AB-N-01-201711HR-119-01).

\section{1) 연구대상}

본 연구는 3 차원(3D) 지방조직유래 간엽줄기세포 조건화 배지 가 함유된 크림 타입 화장품의 피부 자극 개선 및 진정효과를 알 아 보기 위한 연구대상자를 모집하였고 연구대상자는 본 실험에 자발적으로 참여하기를 지원한 20-60대의 여성 중 피시험자 선 정기준에 부합하는 성인여성을 선정하였다. 연구대상들은 본 실 험과 관련된 모든 정보와 취지를 인지하였으며, 연구대상자는 자 발적 의사에 따라 동의서를 작성하도록 하고 실험에 참가하였다.
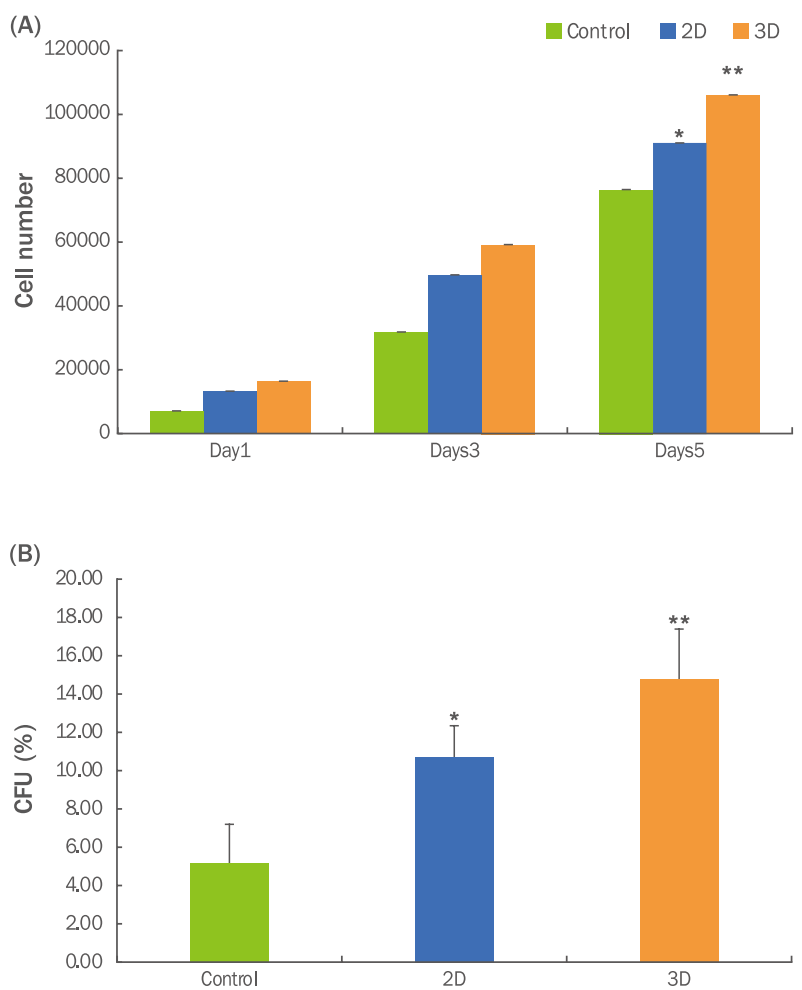

(C)

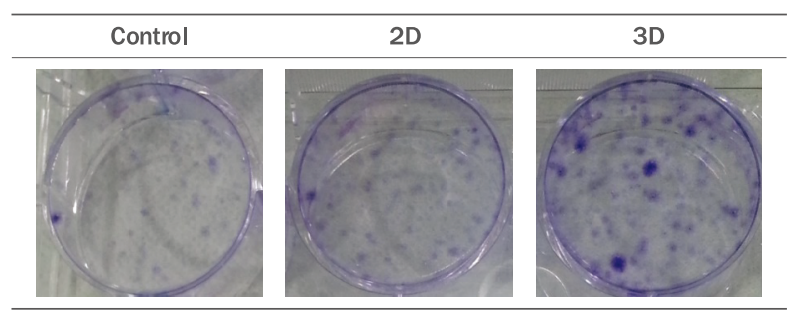

Figure 1. Effects of 3D adipose-derived mesenchymal stem cellconditioned medium on cell growth.

(A) hDF $\left(5 \times 10^{3}\right.$ cells $\left./ \mathrm{cm}^{2}\right)$ were seeded in 6 well plates and treated with control, 2D-ADMSC-CM, and 3D-ADMSC-CM for 1, 3 , and 5 days. Cell counts were measured by ADAM. (B, C) hDF $\left(5 \times 10^{2}\right.$ cells/well) were seeded in 6 well plates and treated with control, 2D-ADMSC-CM, and 3D-ADMSC-CM for 7 days. Colonies were measured with $0.2 \%$ crystal violet staining for $10 \mathrm{~min}$. (B), (C) is the measured image. Graphs indicate mean \pm standard deviation of three independent experiments. The Student's $t$-test was conducted to determine statistical significance. Statistically significant differences are indicated with asterisks $\left({ }^{*} p<0.05\right.$, ${ }^{* *} p<0.01$, compared with the control). CFU, colony forming unit; hDF, human dermal fibroblast; ADMSC-CM, adipose tissue derived mesenchymal stem cell medium.

2) 시험물질의 용법 및 용량

시험 물질은 고온과 직사광선을 피해, 실온 $\left(5-25^{\circ} \mathrm{C}\right)$ 에서 보관 하였다. 


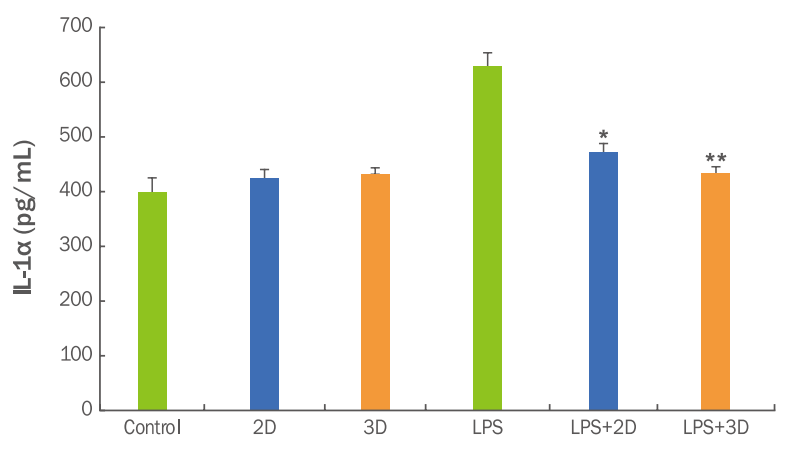

Figure 2. Effects of 3D adipose-derived mesenchymal stem cell conditioned medium on IL-1 $\alpha$ in LPS-stimulated human epidermal keratinocyte.

Cells treated with a $50 \%$ concentration of 2D-ADMSC-CM and 3D-ADMSC-CM were stimulated with or without LPS $(2 \mu \mathrm{g})$ for $24 \mathrm{~h}$. IL-1 $\alpha$ protein levels in the cell-conditioned medium were measured by ELISA. The Student's $t$-test was conducted to determine statistical significance. Statistically significant differences are indicated with asterisks $\left({ }^{*} p<0.05,{ }^{* *} p<0.01\right.$, compared with the LPS treated control). IL-1 $\alpha$, interleukin 1 alpha. 2D, two dimensional; 3D, three dimensional; ADMSC-CM, adipose tissue derived mesenchymal stem cell medium; LPS, lipopolysaccharides; ELISA, enzyme-linked immunosorbent assay.

(1) 동일한 시험 담당자가 모든 피시험자의 tape stripping을 한 양쪽 전완하부 중 왼쪽 전완하부 $\left(1.5 \times 1.5 \mathrm{~cm}^{2}\right)$ 에 일회용 주 사기(disposable syringe, SUNGSHIM MEDICAL CO., LTD, Korea)를 사용하여 시험물질인 '3차원(3D) 지방유래 간엽줄기세 포 조건화 배지 크림' $30 \mu \mathrm{L}$ 를 도포한 후, Latex finger coat를 이 용하여 흡수시켰다.

(2) 피시험자는 시험기간이 3 주 동안 1 일 2 회 아침, 저녁 세정 후 시험물질인 '3차원 $(3 \mathrm{D})$ 지방조직유래 간엽줄기세포 조건화 배지가 함유된 크림 타입 화장품'을 동일한 양을 sodium lauryl sulfate (SLS; BioShop, Canada)를 처리한 양쪽 전완상부 중 왼 쪽 전완상부에 고르게 펴 발라 흡수시켰다.

(3) 인체적용시험기간 중에는 시험물질 이외에 시험결과에 영향을 미칠 수 있는 화장품의 적용을 일체 금하였으며, 팩이나 마사지 등의 시술도 금하였다.

\section{3) SLS 처리에 의한 피부 자극 유도}

본 시험에서는 기기측정에 앞서 피시험자의 양쪽 전완상부에 Finn Chamber (Smart Practice, USA)를 이용하여 SLS 처리를 적용하여 피부 자극을 유도하였다. Filter paper disc를 직경 12 $\mathrm{mm}$ 의 Finn Chamber 내에 얹은 후, SLS $2.0 \%$ 희석액 $60 \mu \mathrm{L}$ 를 적하시켜 시험부위에 첩포하였다. 첩포는 $24 \mathrm{~h}$ 동안 부착하였고, 첩포 제거 $24 \mathrm{~h}$ 경과 후 피부 자극 유무를 육안평가하고 시험물질 도포부위와 무도포부위로 나누어 기기측정을 실시하였다.
4) Tape stripping에 의한 피부 자극 유도

본 시험에서는 기기 측정에 앞서 피시험자의 양쪽 전완하부에 Tape stripping을 하여 피부 자극을 유도하였다. 동일한 시험담 당자가 지정된 시험부위에 $18 \mathrm{~mm}$ 테이프(Scotch ${ }^{\circledR}$ Transparent Tape, $3 \mathrm{M}$ Company, USA)를 부착하여 $2 \mathrm{~s}$ 동안 동일한 압력을 가한 후, 동일한 방향으로 stripping을 하였다. 매회 새로운 테이 프를 이용하여 40회 반복하여 stripping을 하였고, 시험물질 도 포부위와 무도포부위로 나누어 기기측정을 실시하였다.

\section{7. 통계분석 방법}

본 시험의 통계처리는 SPSS 17.0 for windows 프로그램 (IBM, USA)을 이용하여 분석하였다. 피시험자의 설문지 분석을 위하여 평균, 표준편차, 빈도, 백분율을 실시하였고, 다양한 피부 개선도에 대한 기기측정 결과의 유이한 변화 여부를 분석하기 위 하여 paired $t$-test 분석을 실시하였다.

\section{Results and Discussion}

\section{1. 인간피부유래 섬유아세포의 성장률 측정}

인간피부유래 섬유아세포(human dermal fibroblast)를 이용 하여 2차원(2D) 지방조직유래 간엽줄기세포 조건화 배지와 3 차 원(3D) 지방조직유래 간엽줄기세포 조건화 배지의 세포 성장률을 확인하였다. 대조군으로는 인간 진피섬유아세포에 특이적인 배 양액을 사용하였으며 각각의 세포를 포집하여 세포수를 계수하고 도식화하였으며 그 결과는 Figure 1과 같다.

인간피부유래 섬유아세포에 대조군, 2 차원(2D) 지방조직유래 간엽줄기세포 조건화 배지, 3 차원(3D) 지방조직유래 간엽줄기세 포 조건화 배지로 실험 조건을 마련하고 1 일, 3 일, 5 일 동안 처 리하여 세포의 성장률을 측정하였다. 1 일, 3 일, 5 일 동안 3 차원 (3D) 지방조직유래 간엽줄기세포 조건화 배지를 처리하였을 때 인간피부유래 섬유아세포의 생존율이 대조군 대비 $22 \%, 18 \%$, $16 \%$ 증가하였다. 대조군보다 실험군의 세포성장이 유의적으로 증 가하는 것을 확인 할 수 있었으며, 3 차원(3D) 지방조직유래 간엽 줄기세포 조건화 배지로 배양한 경우 2 차원(2D) 지방조직유래 간 엽줄기세포 조건화 배지 보다 세포의 성장에 유의적인 차이가 있 음을 확인하였다(Figure 1A).

인간피부유래 섬유아세포의 경우 간엽줄기세포에 비해 빈도가 낮기는 하지만 $\mathrm{CFU}-\mathrm{F}$ 분석시 콜로니를 형성한다(Hoogduijn et al., 2006). 따라서, 조건화 배지에 의한 세포증식능력과 콜로니 형성을 확인하기 위하여 $\mathrm{CFU}-\mathrm{F}$ 분석을 실시하였다. 배양된 인 간피부유래 섬유아세포의 세포증식 능력은 대조군보다 실험군이 2-3배 정도 더 좋은 것으로 보아 지방조직유래 간엽줄기세포의 배양액이 피부세포 성장과 자기 복제 유지 능력이 우수한 것을 알 
수 있었다. 또한, 2 차원(2D) 지방조직유래 간엽줄기세포 조건화 배지 보다 3차원(3D) 지방조직유래 간엽줄기세포 조건화 배지의 세포 증식률이나 자기 복제능에서 더 우수함을 확인할 수 있었다 (Figure 1B, 1C). 이를 통해, 3차원(3D) 지방조직유래 간엽줄기 세포 조건화 배지를 화장품 원료로 사용시 인간진피섬유아세포의 성장과 피부세포의 자기 복제에 도움이 될 것으로 예상된다.

\section{2. 면역반응억제효능 측정}

인간피부유래 각질형성세포(human epidermal keratinocyte) 에서 3 차원(3D) 지방조직유래 간엽줄기세포 조건화 배지의 $\mathrm{IL}-1 \alpha$ 발현 억제 효과를 확인하기 위해 여러 실험군으로 나누어 실험을 실시하였다. 대조군은 인간피부유래 각질형성세포에 특이 적인 $\mathrm{CEFOgro}^{\mathrm{TM}} \mathrm{HK}$ 배지를 이용하였고 실험군은 2 차원(2D) 지 방조직유래 간엽줄기세포 조건화 배지와 3 차원(3D) 지방조직유래 간엽줄기세포 조건화 배지에 LPS를 처리하여 면역반응이 유도된 환경에서 지방조직유래 간엽줄기세포 조건화 배지의 면역 반응 억 제 효과를 확인할 수 있었다. 그 결과는 Figure 2 와 같다.

인간피부유래 각질형성세포에 $2 \mu \mathrm{g} / \mathrm{mL}$ 의 LPS를 처리 하였을 경우 LPS는 면역반응을 유도하여 IL- $1 \alpha$ 의 발현이 1.5 배 증가하 는 것을 확인할 수 있었다. LPS만 처리한 대조군과 비교하여 볼 때 2 차원(2D), 3 차원(3D) 지방조직유래 간엽줄기세포 조건화 배 지 모두 $\mathrm{IL}-1 \alpha$ 의 발현을 전반적으로 감소시켰다. 특히, 지방조 직유래 간엽 줄기세포 조건화 배지에 의한 면역반응 억제 효과 확 인 시험에서 3 차원(3D) 지방조직유래 간엽줄기세포 조건화 배지 의 경우 LPS만 처리한 대조군 대비 $\mathrm{IL}-1 \alpha$ 의 발현이 1.4 배 감소 하였으며 이는 아무것도 처리하지 않은 대조군(control)과 유사한 수준임을 확인 할 수 있었다. 3 차원(3D) 지방조직유래 간엽줄기 세포 조건화 배지는 2 차원(2D) 지방조직유래 간엽줄기세포 조건 화 배지 보다 면역 반응 억제에 유의적인 차이가 있음을 확인하였 다(Figure 2). 따라서, 3 차원(3D) 지방조직유래 간엽줄기세포 조 건화 배지를 화장품 원료로 사용할 경우 면역반응 억제에 도움이 될 것으로 기대된다. 최근 $\mathrm{ADMSC}$ 의 조건화 배지가 알러지 반응 (allegenic inflammation)을 억제한다는 보고(Kim et al., 2018) 가 있어, 본 연구 결과에 의해 면역억제 성능이 우수한 3 차원(3D) 지방유래 간엽줄기세포 조건화 배지를 적용하면 염증반응을 억제 하고 피부를 진정시키는 효과를 얻을 수 있을 것으로 예상할 수 있다.

\section{3. 인체적용시험}

본 연구에서는 3 차원(3D) 지방조직유래 간엽줄기세포 조건화 배지가 함유된 크림 타입 화장료를 이용하여 진행된 유효성 평가 는 20-60세 성인 여성 22명 대상으로 시행하였다. 시험 전 설문 조사로 일반적인 특성을 분석하고, 22 명의 피시험자를 대상으로 유효성 평가를 진행하였다.

1) 피시험자 설문조사에 의한 피부이상반응 보고

시험담당자는 시험부위에서 피부이상인 홍반(erythema), 부종 (edema), 인설생성(scaling), 가려움(itching), 자통(stinging), 작열감(burning), 뺏뺏함(tightness), 따끔거림(prickling)의 여 부를 관찰하고 피부이상반응이 나타날 시 등급을 표시하여 이에 대한 결과를 작성하였다. 시험담당자에 의한 이상반응 평가와는 별도로, 피시험자를 대상으로 설문조사를 한 결과 피시험자가 보 고한 피부 이상반응은 Table 1과 같다.

피시험자를 대상으로 한 설문조사에서 특별한 피부이상반응은 관찰되지 않았다.

2) 3차원(3D) 지방조직유래 간엽줄기세포 조건화 배지가 함유된 크 림 타입 화장품의 유효성 평가

피부가 자극을 받는 원인은 여러 가지 있을 수 있으며, 그 중에 서도 외부자극(화학적 자극), 물리적 자극(마찰)이 있다. 일반적으 로 물리적 자극이란 어떠한 물리적 에너지에 의해서 피부가 자극 을 받는 것을 의미한다. 또한, 화학적 자극이란 '성질'을 가지고 있 는 화학 물질이 피부를 자극하는 것을 의미한다. 본 연구에서는 3 차원(3D) 지방조직유래 간엽줄기세포 조건화 배지가 함유된 크림 타입 화장품이 피부 자극 개선 및 진정효과에 미치는 영향을 평가 하기 위하여 외부 자극(화학적 자극), 물리적 자극(마찰) 2 가지로 나누어 평가하였다.

(1) 외부 자극(화학적 자극)에 의한 피부 자극 개선 및 진정효과 평 가

본 시험에서는 시험물질의 외부 자극(화학적 자극)에 의한 피 부 자극 개선 및 진정효과 평가를 위하여 ANTERA 3D (Miravex, Ireland)를 적용하였다. ANTERA 3D는 동일한 시험담당자가 모 든 피시험자의 양쪽 전완상부(시험물질 도포부위, 무도포부위) 를 측정하였고, 측정의 재현성을 위하여 시험물질 사용 전에 측정

Table1. Skin adverse reactions reported by the testes

$(\mathbf{N}=\mathbf{2 2})$

\begin{tabular}{lllc}
\hline Adverse reaction & After 3 weeks usage & Adverse reaction & After 3 weeks usage \\
Erythema (erubescence) & 0 & Stinging (ache) & 0 \\
Edema (swollen) & 0 & Buring & 0 \\
Scaling (corneous) & 0 & Tightness & 0 \\
Itching & 0 & Prikling & 0 \\
\hline
\end{tabular}

0 , none; 1 , weak degree; 2 , medium; 3 , severe degree. 


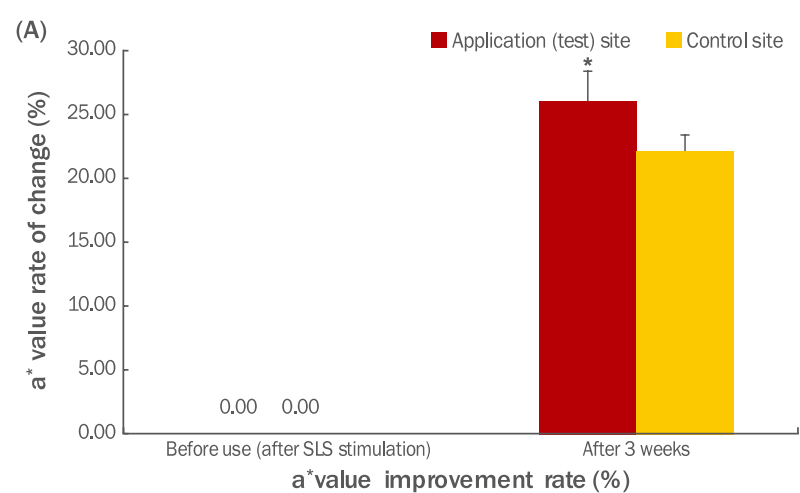

(B)

\begin{tabular}{cccc}
\hline \multicolumn{2}{c}{ Application (test) site } & \multicolumn{2}{c}{ Control site } \\
\hline $\begin{array}{c}\text { Before use } \\
\text { (after SLS stimulation) }\end{array}$ & After 3 weeks & $\begin{array}{c}\text { Before use } \\
\text { (after SLS stimulation) }\end{array}$ & After 3 weeks \\
\hline & & & \\
\hline & & & \\
\hline
\end{tabular}

Figure 3. Comparison of soothing and improvements in skin irritation by an external stimulus (chemical stimulation).

Skin irritation was induced by applying SLS to the upper part of the subject's forearms using a Finn Chamber. The filter paper disc with a diameter of $12 \mathrm{~mm}$ was placed in a fin chamber, and $60 \mu \mathrm{L}$ of a $2.0 \%$ SLS solution was dripped onto the test site. The changes between baseline (after SLS stimulation) and after 3 weeks of test substance use were measured using the ANTERA 3D. (A) is the measured $a^{*}$ value improvement rate, $(B)$ is the measured image. The paired $t$-test was conducted to determine statistical significance $\left(^{*} p<0.05\right)$. SLS, sodium lauryl sulfate.

한 이미지와 오버랩시켜 동일부위를 측정하였다. 촬영된 이미지는 ANTERA 3D 전용 소프트웨어인 ANTERA CS software를 이용 하였다. 기기측정은 시험물질 사용 전(SLS 자극 후)과 3 주 사용 후 의 시점에서 이루어졌다.

ANTERA $3 \mathrm{D}$ 를 이용한 시험 물질 사용 전(SLS 자극 후)과 3 주 사용 후의 외부 자극(화학적 자극)에 의한 피부 지극 개선 및 진정 효과를 평가한 결과는 Figure 3 과 같다. ANTERA 3D를 이용하여 양쪽 전완상부의 외부 자극(화학적 자극)에 의한 피부 자극 개선 및 진정효과 개선도를 분석한 결과, 피부의 붉은기를 나타내는 $\mathrm{a}^{*}$ value가 시험물질 사용 전(SLS 자극 후)과 비교하여 3 주 사용 후 도포부위에서 $25.88 \%$, 무도포부위에서 $22.20 \%$ 로 유의성 있게 감 소되는 변화를 나타내었다(Figure $3 \mathrm{~A}$ ). 피부의 붉은기가 시험물 질 사용 전(SLS 자극 후)과 비교하여 3 주 사용 후 무도포부위 보 다 도포부위에서 더 감소되는 변화를 나타내었다(Figure 3B). 이 와 같은 결과로 볼 때, 3 차원(3D) 지방조직유래 간엽줄기세포 조 건화 배지가 함유된 크림 타입 화장품은 외부 자극(화학적 자극)에

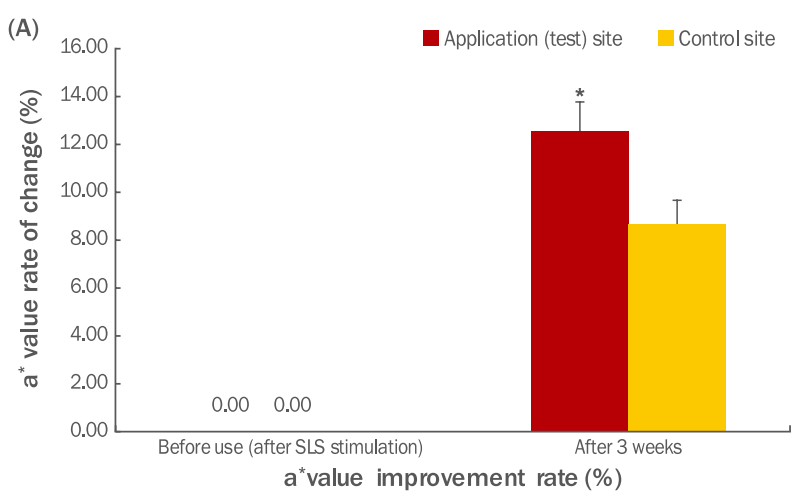

(B)

\begin{tabular}{cccc}
\hline \multicolumn{2}{c}{ Application (test) site } & \multicolumn{2}{c}{ Control site } \\
\hline $\begin{array}{c}\text { Before use } \\
\text { (after SLS stimulation) }\end{array}$ & After 1 use & $\begin{array}{c}\text { Before use } \\
\text { (after SLS stimulation) }\end{array}$ & After 1 use \\
\hline & & & \\
\hline
\end{tabular}

Figure 4. Soothing effect on physical skin irritation (friction).

Tape strips were applied to the lower part of both forearms to induce skin irritation. The same experimenter stripped in the same direction, after applying the same pressure for 2 seconds, by attaching an $18 \mathrm{~mm}$ strip of tape (Scotch ${ }^{\circledR}$ Transparent Tape, 3M Company, USA) to the designated test site. The stripping was repeated 40 times with new tape every time. Measurements were made on the application and control sites. ANTERA 3D was used to evaluate the sedative effects of skin irritation. $(A)$ is measured $a^{*}$ value improvement rate, $(B)$ is the measured image. The paired $t$-test was conducted to determine statistical significance $\left({ }^{*} p<0.05\right)$. SLS, sodium lauryl sulfate.

의한 피부 자극 개선 및 진정효과에 도움을 주는 것으로 판단된다.

(2) 물리적 자극(마찰)에 의한 피부 자극 진정효과 평가

본 시험에서는 시험물질의 물리적 자극(마찰)에 의한 피부 자극 진정효과 평가를 위하여 ANTERA $3 \mathrm{D}$ 를 적용하였다. 동일한 시 험담당자가 모든 피시험자의 양쪽 전완하부(시험물질 도포부위, 무도포부위)를 측정하였고, 측정의 재현성을 위하여 시험물질 사 용 전에 측정한 이미지와 오버랩시켜 동일부위를 측정하였다. 촬 영된 이미지는 ANTERA 3D 전용 소프트웨어인 ANTERA CS software를 이용하였다. 기기측정은 시험물질 사용 전(자극 후) 과 1 회 사용 직후의 시점에서 이루어졌다.

ANTERA 3D를 이용한 시험 물질 사용 전(SLS 자극 후)과 1회 사용 직후의 물리적 자극(마찰)에 의한 피부 자극 진정효과를 평 가한 결과는 Figure 4 와 같다. ANTERA $3 \mathrm{D}$ 를 이용하여 양쪽 전 완하부의 물리적 자극(마찰)에 의한 피부 자극 진정효과 개선도를 


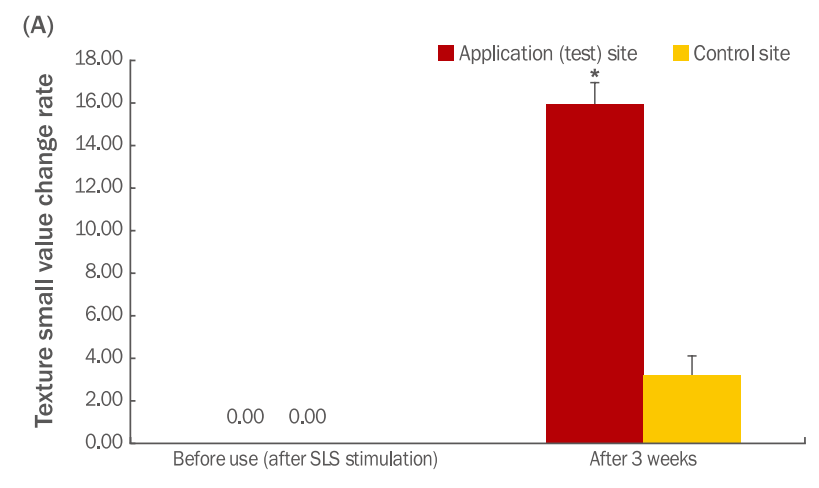

(B)

\begin{tabular}{cccc}
\hline \multicolumn{2}{c}{ Application (test) site } & \multicolumn{2}{c}{ Control site } \\
\hline $\begin{array}{c}\text { Before use } \\
\text { (after SLS stimulation) }\end{array}$ & After 3 weeks & $\begin{array}{c}\text { Before use } \\
\text { (after SLS stimulation) }\end{array}$ & After 3 weeks \\
\hline & & & \\
& & & \\
\hline
\end{tabular}

Figure 5. Analysis of rough skin damage induced by external stimuli.

The upper parts of both forearms (both application and control sites) were measured, and the same site was tested for measurement reproducibility by overlapping with baseline (pre-application) image. These images were matched using ANTERA 3D software, ANTERA CS software, and the matched measurement sites were used for analysis. (A) represents the texture improvement rate, $(B)$ is the measured image. The paired $t$-test was conducted to determine statistical significance ( $p<0.05)$. SLS, sodium lauryl sulfate.

분석한 결과, 피부의 붉은기를 나타내는 $\mathrm{a}^{*}$ value가 시험물질 사 용 전(자극 후)과 비교하여 1 회 사용 직후 도포부위에서 $12.53 \%$, 무도포부위에서 $8.71 \%$ 로 유의성 있게 감소되는 변화를 나타내었 다(Figure $4 \mathrm{~A})$. 피부의 붉은기는 시험물질 사용 전(자극 후)과 비 교하여 1 회 사용 직후 도포부위에서 감소되는 변화를 나타내었다 (Figure 4B). 따라서, 1 회 사용 직후 3 차원(3D) 지방조직유래 간 엽줄기세포 조건화 배지가 함유된 크림 타입 화장품은 물리적 자 극(마찰)에 의한 피부 자극 진정효과에 도움을 주는 것으로 판단 된다.

(3) 외부 자극에 의한 손상된 거친 피부결 개선 평가

본 시험에서는 시험물질의 외부 자극에 의한 손상된 거친 피부 결 개선 평가를 위하여 ANTERA3D를 적용하였다. 동일한 시험 담당자가 모든 피시험자의 양쪽 전완상부(시험물질 도포부위, 무 도포부위)를 측정하였고, 측정의 재현성을 위하여 시험물질 사 용 전에 측정한 이미지와 오버랩 시켜 동일부위를 측정하였다. 촬

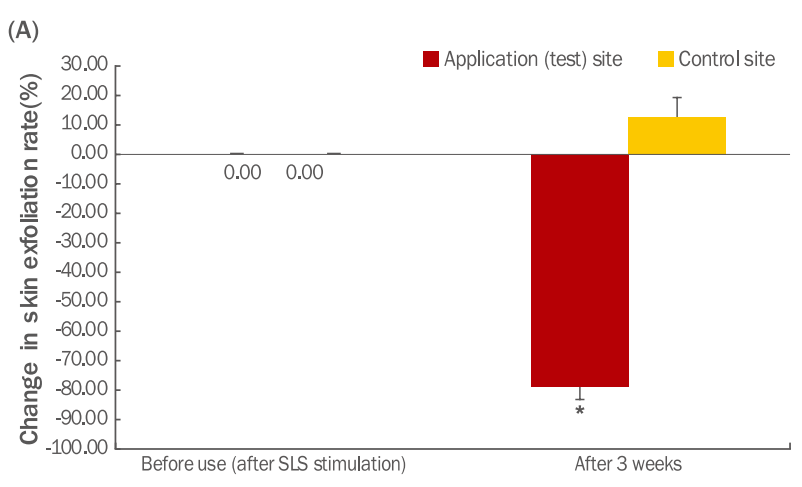

(B)

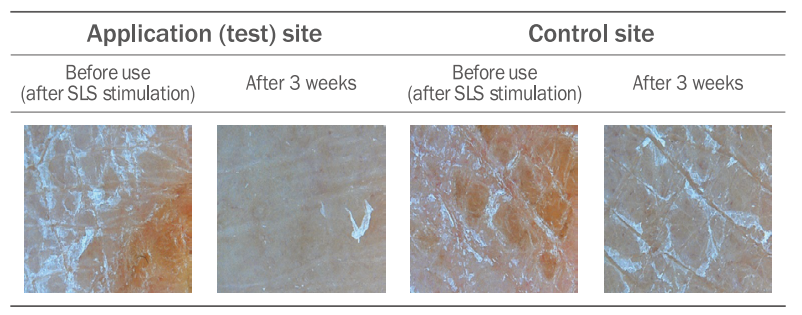

Figure 6. Improved exfoliation and soothing of skin damaged by external stimuli.

Video microscopy measures of the upper part of both forearms (both the application and control sites) of all subjects using 300 times magnification, and in the same position as the uniformed illumination for consistent imaging. $(A)$ is the change in the rate of skin exfoliation, $(B)$ is the measured image. The paired $t$-test was conducted to determine statistical significance $\left({ }^{*} p<0.05\right)$. SLS, sodium lauryl sulfate.

영된 이미지는 ANTERA 3D 전용 소프트웨어인 ANTERA CS software를 이용하여 매칭시킨 후 일치된 측정부위를 분석에 사 용하였다. 기기측정은 시험물질 사용 전(SLS 자극 후)과 3 주 사 용 후의 시점에서 이루어졌다.

ANTERA $3 \mathrm{D}$ 를 이용한 시험 물질 사용 전(SLS 자극 후)과 3 주 사용 후의 외부 자극에 의한 손상된 거친 피부결 개선을 평가 한 결과는 Figure 5 와 같다. ANTERA $3 \mathrm{D}$ 를 이용하여 양쪽 전 완상부의 외부 자극에 의한 손상된 거친 피부결 개선도를 분석 한 결과, 피부의 거칠기를 나타내는 texture small 값이 시험물 질 사용 전(SLS 자극 후)과 비교하여 3 주 사용 후 도포부위에 서 $15.91 \%$, 무도포부위에서 $3.16 \%$ 로 유의성 있게 감소되는 변 화를 나타내었다(Figure $5 \mathrm{~A}$ ). 피부의 거칠기는 시험물질 사용 전(SLS 자극 후)과 비교하여 3 주 사용 후 도포부위에서 감소되 는 변화를 나타내었다(Figure 5B). 이와 같은 결과로 유추해 볼 때, 3 차원(3D) 지방조직유래 간엽줄기세포 조건화 배지가 함유 된 크림 타입 화장품은 외부 자극에 의한 손상된 거친 피부결 개 선에 도움을 주는 것으로 판단된다. 
(4) 외부 자극(손상)에 의한 각질 들뜸 개선 및 진정효과 평가

본 시험에서는 시험물질의 외부 자극(손상)에 의한 각질 들 뜸 개선 및 진정효과 평가를 위하여 비디오 마이크로 스코프 (KONG PC Camera, Bomtech, Korea)와 이미지 분석프로그 램(Image J, National Institutes of Health, USA)을 적용하 였다. 비디오 마이크로 스코프는 일관된 촬영을 위하여 균일한 조명과 동일한 포지션에서 동일한 시험담당자가 모든 피시험자 의 양쪽 전완상부(시험물질 도포부위, 무도포부위)를 300 배 확 대하여 측정하였다. 기기측정은 시험물질 사용 전(SLS 자극 후) 과 3 주 사용 후의 시점에서 이루어졌다.

비디오 마이크로 스코프와 이미지 분석프로그램을 이용한 시 험 물질 사용 전(SLS 자극 후)과 3주 사용 후의 외부 자극(손상) 에 의한 각질 들뜸 개선 및 진정효과를 평가한 결과는 Figure 6 과 같다. 비디오 마이크로 스코프와 이미지 분석프로그램을 이 용하여 양쪽 전완상부의 외부 자극(손상)에 의한 각질 들뜸 개 선 및 진정효과 개선도를 분석한 결과, 피부 각질도가 시험 물 질 사용 전(SLS 자극 후)과 비교하여 3주 사용 후 도포부위에서 $78.28 \%$ 감소, 무도포부위에서 $12.26 \%$ 로 증가되어 유의성 있는 변화를 나타내었다(Figure $6 \mathrm{~A}$ ). 피부 각질도가 시험물질 사용 전(SLS 자극 후)과 비교하여 3 주 사용 후 무도포부위 대비 도 포부위에서 감소되는 변화를 나타내었다(Figure 6B). 결과적으 로, 3 차원(3D) 지방조직유래 간엽줄기세포 조건화 배지가 함유 된 크림 타입 화장품은 외부 자극(손상)에 의한 각질 들뜸 개선 및 진정효과에 도움을 주는 것으로 판단된다.

\section{Conclusion}

3 차원(3D) 지방유래 간엽줄기세포 조건화 배지를 화장품 원 료로 사용 가능 여부를 검증하기 위하여 다양한 연구를 진행한 결과 다음과 같은 결론을 얻었다.

첫째, 3 차원(3D) 지방유래 간엽줄기세포 조건화 배지가 세포 성장률에 미치는 영향을 조사한 결과 3 차원(3D) 지방유래 간 엽줄기세포 조건화 배지를 1 일, 3 일, 5 일 동안 처리한 결과 대 조군 대비 $22 \%, 18 \%, 16 \%$ 세포 성장률이 증가하였다(Figure $1 \mathrm{~A})$. 인간진피섬유아세포가 분열하여 콜로니를 형성하는 것을 확인 하기 위하여 $\mathrm{CFU}$ 분석을 하였으며 그 결과, 2 차원(2D) 지방유래 간엽줄기세포 조건화 배지 보다 3 차원(3D) 지방유래 간엽줄기세포 조건화 배지의 세포 증식률이나 자기 복제능에서 대조군 보다 실험군이 2-3배더 우수함을 알 수 있었다(Figure 1B, 1C).

둘째, 배지에 LPS를 처리하여 면역반응이 유도된 환경에서 지방유래 간엽줄기세포 조건화 배지의 면역 반응 억제 효과를 확인하였다. 3 차원(3D) 지방유래 간엽줄기세포 조건화 배지의
경우는 $\mathrm{LPS}$ 처리군 대비 $\mathrm{IL}-1 \alpha$ 의 발현이 1.4 배 감소하였으 며 이는 LPS를 처리하지 않은 대조군과 유사한 수준임을 확인 할 수 있었다(Figure 2).

이와 같이, 생체외(in vitro) 실험을 통해 3차원(3D) 지방유 래 간엽줄기세포 조건화 배지는 화장품의 원료 물질로 문제가 없다고 판단하여 3 차원(3D) 지방유래 간엽줄기세포 조건화 배 지가 함유된 크림을 제조하여 인체적용시험으로 유효성을 확인 하였다.

이에 본 연구에서는 성인 여성 22 명의 피시험자를 대상으로 ' 3 차원(3D) 지방조직유래 간엽줄기세포 조건화 배지가 함유된 크림 타입 화장품'을 이용하여 인체적용시험을 진행하였다.

셋째, 시험 물질 사용 전(SLS 자극 후)과 비교하여 3주 사용 후 도포부위에서 $25.88 \%$, 무도포부위에서 $22.20 \%$ 감소되어 3 차원(3D) 지방조직유래 간엽줄기세포 조건화 배지가 함유된 크림 타입 화장품은 외부 자극(화학적 자극)에 의한 피부 자극 개선 및 진정효과에 도움을 주는 것으로 판단된다(Figure 3).

넷째, 시험 물질 사용 전(SLS 자극 후)과 비교하여 1회 사용 직후의 도포부위 $12.53 \%$, 무도포부위에서 $8.71 \%$ 가 감소되어 3 차원(3D) 지방조직유래 간엽줄기세포 조건화 배지가 함유된 크림 타입 화장품 은 물리적 자극(마찰)에 의한 피부 자극 진정 효과에 도움을 주는 것으로 판단된다(Figure 4).

다섯째, 시험 물질 사용 전(SLS 자극 후)과 비교하여 3 주 사 용 후 도포부위에서 $15.91 \%$, 무도포부위에서 $3.16 \%$ 가 감소 되어 3 차원(3D) 지방조직유래 간엽줄기세포 조건화 배지가 함 유된 크림 타입 화장품은 외부 자극에 의한 손상된 거친 피부 결 개선에 도움을 주는 것으로 판단된다(Figure 5).

여섯째, 시험 물질 사용 전(SLS 자극 후)과 비교하여 3 주 사 용 후 도포부위에서 $78.28 \%$ 감소, 무도포부위에서 $12.26 \%$ 증가되어 3 차원(3D) 지방조직유래 간엽줄기세포 조건화 배지 가 함유된 크림 타입 화장품은 외부 자극(손상)에 의한 각질 들 뜸 개선 및 진정효과에 도움을 주는 것으로 판단된다(Figure $6)$.

종합적으로 판단할 때, 3 차원(3D) 지방유래 간엽줄기세포 조건화 배지는 세포의 성장, 면역 반응 억제 효과를 체외 실험 을 통해 유의적인 결과를 나타냈다. 3차원(3D) 지방조직유래 간엽줄기세포 조건화 배지가 함유된 크림 타입 화장품은 외부 자극(화학적 자극)에 의한 피부 자극 개선 및 진정효과, 물리적 자극(마찰)에 의한 피부 자극 진정효과, 외부 자극에 의한 손상 된 거친 피부결 개선, 외부 자극(손상)에 의한 각질 들뜸 개선 및 진정효과에 유의적인 결과를 나타냈다. 이러한 결과를 종합 해볼 때, 3 차원(3D) 지방조직유래 간엽줄기세포 조건화 배지 가 함유된 크림 타입 화장품은 피부 자극(외부 자극, 물리적 자 극), 거친 피부결, 각질 들뜸 등의 피부 진정 및 개선에 효과적 인 것으로 판단된다. 


\section{References}

Baek YM, Choi JY, Lee CW, Jeon YS, Han JT, Jang SI, Yoo HS. Effects of Chinemys reevesii on lipopolysaccarideindused inflammatory reactions. Korean Journal of Oriental Physiology \& Pathology, 26: 26-34, 2012.

Breslin S, O' Driscoll L. Three-dimensional cell culture: the missing link in drug discovery. Drug Discovery Today, 18: 240-249, 2013.

Choi EJ, Cho HB, Yoon HS. Developments of culture media for human skin stem cell, and evaluation of efficacy of cosmetics containing culture media. Asian Journal of Beauty and Cosmetology, 10: 949-960, 2012.

Hoogduijn MJ, Gorjup E, Genever PG. Comparative characterization of hair follicle dermal stem cells and bone marrow mesenchymal stem cells. Stem Cells and Development, 15: 49-60, 2006.

Jang WY, Lee CR, Seo SM, Lee B, Kim MS, Khang G, Lee HG, Lee HB. Transdermal delivery of FITC-ovalbumin with microneedle system. Journal of Pharmaceutical Investigation, 35: 403-409, 2005.

Jukanti R, Sheela S, Bandari S, Veerareddy PR. Enhanced bioavailability of exemestane via proliposomes based transdermal delivery. Journal of Pharmaceutical Sciences, 100: 3208-3222, 2011.

Kenny PA, Lee GY, Myers CA, Neve RM, Semeiks JR, Spellman PT, Lorenz K, Lee EH, Barcellos-Hoff MH, Petersen OW, et al. The morphologies of breast cancer cell lines in three-dimensional assays correlate with their profiles of gene expression. Molecular Oncology, 1: 84-96, 2007.

Kim M, Lee SH, Kim Y, Kwon Y, Park Y, Lee HK, Jung HS, Jeoung D. Human adipose tissue-derived mesenchymal stem cells attenuate atopic dermatitis by regulating the expression of MIP-2, miR-122a-SOCS1 axis, and Th1/ Th2 responses. Frontiers in Pharmacology, 9: 1175, 2018.

Kim SM, Kim BH. Anti-wrinkle effect of ADMSCs-CM in photoaging skin model of hairless mice. Journal of the Korean Society of Cosmetology, 17: 689-696, 2011.

Kim WS, Park BS, Sung JH, Yang JM, Park SB, Kwak SJ, Park
JS. Wound healing effect of adipose-derived stem cells: a critical role of secretory factors on human dermal fibroblast. Journal of Dermatological Science, 48: 15$24,2007$.

Kim WS, Park BS, Sung JH. Protective role of adipose-derived stem cells and their soluble factors in photoaging. Archives of Dermatological Research, 301: 329-336, 2009.

Lee HJ, Sim BY, Bak JW, Kim DH. Effect of Gami-sopungsan on inflammation and DNCB-induced dermatitis in NC/ Nga in mice. Korean Journal of Oriental Physiology \& Pathology, 28: 146-153, 2014.

Lee JY, Park WS. Anti-inflammatory effect of myristicin on RAW 264.7 macrophages stimulated with polyinosinicpolycytidylic acid. Molecules, 16: 7132-7142, 2011.

Nakagawa H, Akita S, Fukui M, Fujii T, Akino K. Human mesenchymal stem cells successfully improve skin-substitute wound healing. British Journal of Dermatology, 153: 29-36, 2005.

Sachlos E, Czernuszka JT. Making tissue engineering scaffolds work. review: the application of solid freeform fabrication technology to the production of tissue engineering scaffolds. European Cells and Materials, 5: 29-40, 2003.

Schinköthe $\mathrm{T}$, Bloch $\mathrm{W}$, Schmidt $\mathrm{A}$. In vitro secreting profile of human mesenchymal stem cells. Stem Cells and Development, 17: 199-206, 2008.

Strem BM, Hicok KC, Zhu M, Wulur I, Alfonso Z, Schreiber $\mathrm{RE}$, Fraser JK, Hedrick MH. Multipotential differentiation of adipose tissue-derived stem cells. The Keio Journal of Medicine, 54: 132-141, 2005.

Weissman IL, Anderson DJ, Gage F. Stem and progenitor cells: origins, phenotypes, lineage commitments, and transdifferentiations. Annual Review of Cell and Developmental Biology, 17: 387-403, 2001.

Weissman IL. Stem cells: units of development, units of regeneration, and units in evolution. Cell, 100: 157-168, 2000.

Wilson A, Butler PE, Seifalian AM. Adipose-derived stem cells for clinic applications: a review. Cell Proliferation, 44: 86-98, 2011. 


\section{국문초록}

\section{3차원(3D) 지방조직유래 간엽줄기세포 조건화 배지의 면역반응 억제 능력과 이를 함 유한 크림 타입 화장품의 유효성 평가}

김경혜 ${ }^{1,2 *}$. 이순례 ${ }^{3}$, 박현숙 $^{3}$

${ }^{1}$ 건국대학교 산업대학원 향장학과, 서울, 한국

${ }^{2}$ 동구바이오제약 신규사업팀, 서울, 한국

${ }^{3}$ 세포바이오 부설연구소, 서울, 한국

목적: 본 논문에서는 3 차원(3D) 지방조직유래 간엽줄기세포 조건화 배지의 효능을 확인하고, 3 차원(3D) 지방조직유래 간엽줄기세 포 조건화 배지가 함유된 크림이 피부 자극 개선 및 진정효과에 대한 인체효능에 대해 평가하고자 한다. 방법: 3 차원(3D) 지방조직 유래 간엽줄기세포 조건화 배지를 이용하여 세포 성장률, 면역반응억제 효과 등의 효능을 확인 한 후, 3 차원(3D) 지방조직유래 간엽 줄기세포 조건화 배지를 함유한 크림 제형의 화장품의 유효성 평가를 진행한다. 결과: 3 차원(3D) 지방조직유래 간엽줄기세포 조건 화 배지는 세포의 성장(1일, 3 일, 5 일)과 자기 복제능이 우수하며, 면역반응 억제력은 LPS 처리군 대비 $\mathbb{L}-1 \alpha$ 의 발현이 1.4 배 감소 함을 확인하였다. 3 차원(3D) 지방조직유래 간엽줄기세포 조건화 배지가 함유된 크림의 인체적용시험을 확인하였다. 외부자극(화학 적 자극)에 의한 피부 자극 개선 및 진정효과는 시험물질 사용 전 (SLS 자극 후)과 비교하여 3 주 사용 후 도포부위 $25.88 \%$, 무도포 부위 $22.20 \%$ 가 감소되는 변화를 나타내었다. 1 회 사용 직후의 물리적 자극(마찰)에 의한 피부 자극 진정효과는 도포부위 $12.53 \%$, 무도포부위 $8.71 \%$ 가 감소되는 변화를 나타내었다. 외부 자극에 의한 손상된 거친 피부결 개선 평가는 사용 전(SLS 자극 후)과 비 교하여 3 주 사용 후 도포부위에서 $15.91 \%$, 무도포부위에서 $3.16 \%$ 가 감소되는 변화를 나타내었다. 외부 자극(손상)에 의한 각질 들 뜸 개선 및 진정효과 개선도를 분석한 결과, 피부 각질도가 시험물질 사용 전(SLS 자극 후)과 비교하여 3 주 사용 후 도포부위에서 $78.28 \%$ 감소, 무도포부위에서 $12.26 \%$ 증가되는 변화를 나타내었다. 결론: 본 연구는 3 차원(3D) 지방조직유래 간엽줄기세포 조건 화 배지의 효능 검증과 피부 자극 개선 및 진정효과에 대해 규명하였다. 결과를 종합해볼 때, 3 차원(3D) 지방조직유래 간엽 줄기세 포 조건화 배지가 함유된 크림은 피부 자극(외부 자극, 물리적 자극), 거친 피부결, 각질 들뜸 등의 피부 진정 및 개선에 유의적인 효 과가 있는 것으로 판단된다.

핵심어: 줄기세포배양액, 화장품, 피부자극, 진정, 효능평가

\section{참고문헌}

김상미, 김배환. Hairless mice를 이용한 광노화 피부모델에서 줄기세포배양액의 주름억제효과. 한국미용학회지, 17 : 689-696, 2011.

백영미, 최정은, 이철우, 전영석, 한진택, 장성일, 유화승. 구판의 LPS로 유도된 염증 반응 억제 효과. 동의생리병리학회 지, 26: 26-34, 2012.

이해진, 심부용, 박지원, 김동희. 加味消風散이 염증 및 아토피피부염 동물병태에 미치는 영향. 동의생리병리학회지, 28 : 146-153, 2014.

장우영, 이창래, 서성미, 이봉, 김문석, 강길선, 이한구, 이해방. 마이크로 피부침을 이용한 FITC-OVA의 경피흡수. Journal of Pharmaceutical Investigation, 35: 403-409, 2005.

정지연, 한효선. 화장품의 경피 흡수에 대한 최신 연구 동향. 아시안뷰티화장품학술지, 12: 597-605, 2014.

최은주, 조홍범, 윤현수. 인간 피부줄기세포 배지의 개발과 이를 조성물로 제조한 화장품의 유효성 평가. 아시안뷰티화장 품학술지, 10: 949-960, 2012. 


\title{
中文摘要
}

\section{三维脂肪组织间充质干细胞条件培养液的免疫应答抑制作用以及对其乳亳有效 性评价}

\author{
金京慧 $12^{*}$, 李順禮 ${ }^{3}$, 朴賢淑 $^{3}$ \\ 建国大学产业大学院香妆学科, 首尔, 韩国 \\ ${ }^{2}$ DongKoo生物制药新业务団队，首尔，韩国 \\ 细胞生物技术研究所, 首尔, 韩国
}

目的: 本论文旨在确认3D脂肪组织间充质干细胞条件培养基（3D-ADMSC-CM）的功效以及研究含有3D-ADMSCCM的乳膏的人体功效。方法: 利用 $3 D-A D M S C-C M$ 确认抑制细胞生长率和免疫抑制效果, 并评估含有 3D-ADMSC-CM的乳膏对人体皮肤的影响。结果: 与LPS处理相比, 3D-ADMSC-CM显示出优异的自我复制和细 胞生长速率（在1，3和5日），并且白细胞介素 $1 \alpha （ I L-1 \alpha ）$ 的表达减少了1.4倍。然后我们将3D-ADMSC-CM应 用于人体皮肤。外用刺激（化学刺激）对皮肤刺激的改善和镇静作用在使用 3 周后, 在施用区域减少 $25.88 \%$, 在非施用区域减少 $22.20 \%$ 。一次使用后立即通过物理刺激（摩擦）引起的皮肤刺激镇静作用显示施用面积减少 $12.53 \%$ ，未施用部分减少 $8.71 \%$ 。使用后3周后皮肤粗粮度降低至施用部分的 $15.91 \%$ 和未施用部分的 $3.16 \%$ ， 与使用前的试验材料相比。最终结果表明, 与使用前的测试材料相比, 使用后3周后, 角蛋白激发和剥离的改善 已降低至应用部分的 $78.28 \%$ 和未施用部分的 $12.26 \%$ 。结论: 3D-ADMSC-CM有效并提供足够的皮肤刺激。含有 3D-ADMSC-CM的乳霜舒缓皮肤刺激, 改善皮肤的整体色调和质地, 并通过皮肤刺激（化学和物理刺激）恢复去 角质。

关键词: 干细胞条件培养基, 化妆品, 皮肤刺激, 舒缓, 功效评价 